Two New Harpellales Inhabiting the Digestive Tracts of Midge Larvae and Other Trichomycetes from Tianshan Mountains, China

Author(s): Juan Wang, Shengquan Xu and D. B. Strongman

Source: Mycologia, Vol. 102, No. 1 (Jan. - Feb., 2010), pp. 135-141

Published by: Mycological Society of America

Stable URL: http://www.jstor.org/stable/20619276

Accessed: 17-06-2015 12:13 UTC

\title{
REFERENCES
}

Linked references are available on JSTOR for this article:

http://www.jstor.org/stable/20619276?seq=1\&cid=pdf-reference\#references_tab_contents

You may need to log in to JSTOR to access the linked references.

Your use of the JSTOR archive indicates your acceptance of the Terms \& Conditions of Use, available at http://www.jstor.org/page/ info/about/policies/terms.jsp

JSTOR is a not-for-profit service that helps scholars, researchers, and students discover, use, and build upon a wide range of content in a trusted digital archive. We use information technology and tools to increase productivity and facilitate new forms of scholarship. For more information about JSTOR, please contact support@jstor.org. 


\section{Two new Harpellales inhabiting the digestive tracts of midge larvae and other trichomycetes from Tianshan Mountains, China}

\author{
Juan Wang \\ Shengquan $\mathrm{Xu}^{1}$ \\ College of Life Science, Shaanxi Normal University, \\ Xi'an, PR China

\section{D.B. Strongman} \\ Biology Department, Saint Mary's University, 923 Robie \\ Street, Halifax, Nova Scotia, B3H 3C3 Canada
}

\begin{abstract}
Two new taxa of gut fungi within order Harpellales (Kickxellomycotina) are described from a stream in the Tianshan Mountains in northwestern China. These include the new genus and species, Sinotrichium chironomidarum J. Wang, S.Q. Xu \& Strongman, and the new species, Stachylina tianensis J. Wang, S.Q. Xu \& Strongman, both living in the guts of aquatic chironomid larvae. We also extend the geographic range of Smittium rupestre, previously known only from Australia. A Harpellid specimen not fully identified and a species of Paramoebidium (Amoebidiales) also are documented.
\end{abstract}

Key words: aquatic insects, endobionts, Harpellales, Sinotrichium, Stachylina

\section{INTRODUCTION}

Trichomycetes are an ecological group of microorganisms that live symbiotically in the digestive tract of the arthropod classes Insecta, Crustacea and Diplopoda (Lichtwardt 1986, Hibbett et al 2007). The majority of arthropods known to be associated with these gut fungi live in freshwater habitats; these include larvae of a number of families of flies (Diptera), mayflies (Ephemeroptera), stoneflies (Plecoptera), caddisflies (Trichoptera) and beetles (Coleoptera). Adults of some terrestrial isopods, diplopods, springtails (Collembola) and diverse marine crustaceans are known to house trichomycetes in their intestinal tract (Lichtwardt et al 2001).

The known worldwide distribution of trichomycetes includes all continents except Antarctica (Lichtwardt et al 2001). The majority of trichomycetes have been described from Europe and the United States and are still poorly known from China. The first report of these endosymbionts in China was the occurrence of Harpella melusinae Leger \& Duboscq, on the peri-

Submitted 12 Dec 2008; accepted for publication 29 Jun 2009

${ }^{1}$ Corresponding author. E-mail: xushengquan@snnu.edu.cn trophic matrix of black fly larvae (Adler et al 1996). Chien and Hsieh (2001) reported trichomycetes in orders Eccrinales and Asellariales from freshwater, terrestrial and marine arthropods in Taiwan. The latest was a report describing three species of Smittium, S. naiadis Strongman \& S.Q. Xu, S. nodifixum Strongman \& S.Q. Xu and S. chinliense Strongman \& S.Q. Xu, from Qinling Mountains near Xi'an, the capital of Shaanxi Province, and several other trichomycete species that were new geographic records for the country (Strongman and Xu 2006).

In this paper we present a taxonomic study and information on the ecology of trichomycetes from aquatic insects in Houxia area, Tianshan Mountains, about $80 \mathrm{~km}$ from Urumqi, Xinjiang Province, in northwestern China. We describe a new genus and species of a trichomycete in order Harpellales. We also record previously known species for the first time from China: Smittium rupestre Lichtw. and possibly a Lancisporomyces sp. or Genistelloides sp.

\section{MATERIALS AND METHODS}

Collections were made in streams from the Houxia area $\left(43^{\circ} 13^{\prime} 39.11^{\prime \prime} \mathrm{N} 87^{\circ} 09^{\prime} 10.60^{\prime \prime} \mathrm{E}, 2223 \mathrm{~m}\right)$ and Baiyanggou area $\left(43^{\circ} 27^{\prime} 12.98^{\prime \prime} \mathrm{N} 87^{\circ} 12^{\prime} 43.33^{\prime \prime} \mathrm{E}, 1857 \mathrm{~m}\right)$, western China on 21 and 30 Aug 2007 and 7 Sep 2007 (FIG. 1). Hosts including Ephemeroptera, Diptera and Plecoptera were collected from gravel or rocky cobblestone bottoms in fast flowing water by disturbing the substrate and collecting released arthropods in an aquatic net downstream (kicksampling) (Lichtwardt et al 2001). Living larvae were kept in collecting bags placed on ice for transport to the laboratory. In the laboratory the peritrophic matrix (in dipterans) and hindgut of all insects were dissected in distilled water, with the aid of forceps and needles. Slides (wet mounts) were examined with phase-contrast microscopy, and any trichomycetes present were photographed. Semipermanent voucher slides were made by fixing and staining with lactophenol-cotton blue and sealing the cover slip with clear nail polish (Lichtwardt et al 2001). Fungal identifications were made with the Lucid keys available at the University of Kansas Trichomycete Website (Lichtwardt et al 2001). Type specimens of new species are deposited in SANU, Life Science College, Shaanxi Normal University, Xi'an, 710062, People's Republic of China.

\section{TAXONOMY}

Sinotrichium J. Wang, S.Q. Xu \& Strongman, gen. nov. 


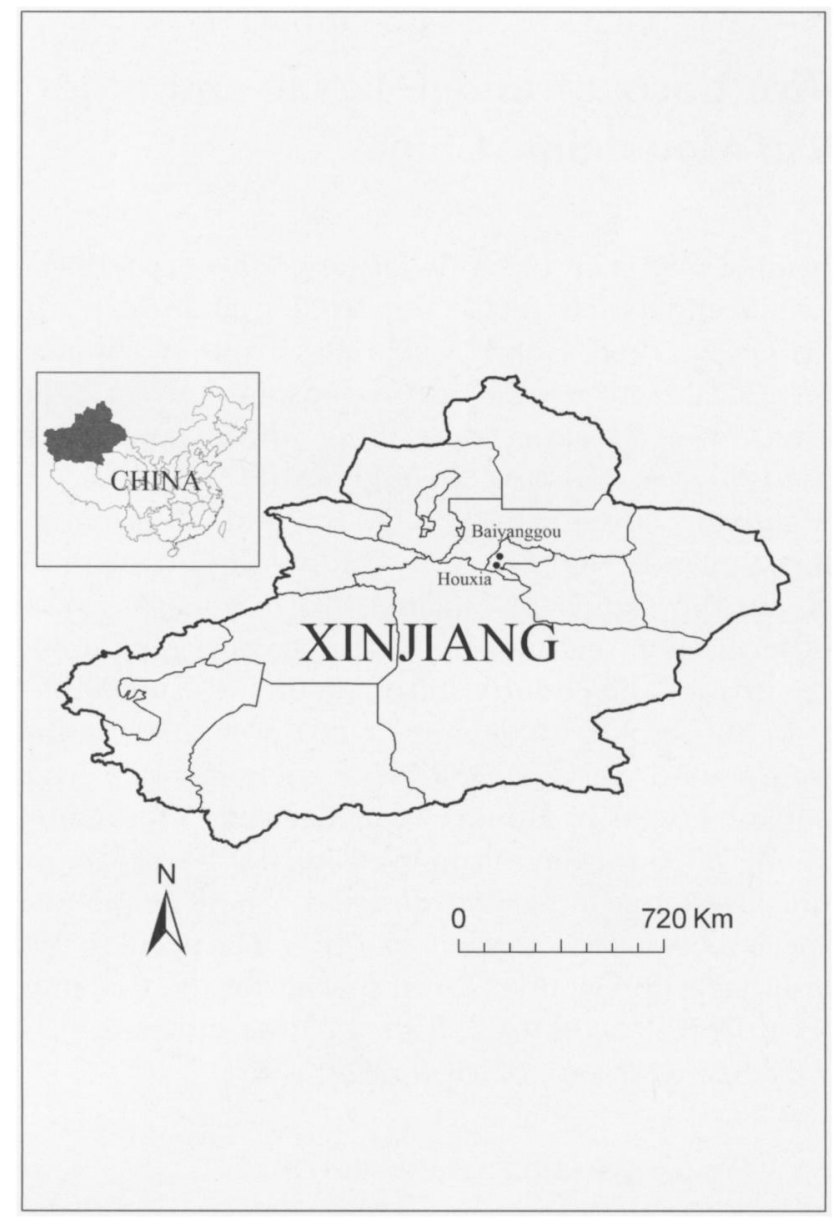

FIG. 1. Collection sites in Urumqi, Xinjiang, China. Inset shows the location of Xinjiang region in northwestern China.

\section{Mycobank MB 513199}

Thallus densus regularitim ramosus; trichosporae cylindricae, collo basi appendiceque singulari longa instructae. Zygosporae biconicae, ad zygosporophora oblique affixae, collum et appendices multiplices grossas ferentes. Ad cuticulam proctodaei larvarum chironomidarum affixus.

Dense, regularly branched thallus, trichospores cylindrical, with a collar at the base and one long appendage. Zygospores biconical, attached obliquely to the zygosporophores, with a collar and multiple coarse appendages. Attached to hindgut cuticle of chironomid larvae.

Etymology. From the Greek "Sina" referring to the country of origin (China) and "trichos" in reference to the hair-like appendages on the zygospores.

Type species. Sinotrichium chironomidarum J. Wang, S. Xu \& Strongman.

Sinotrichium chironomidarum J. Wang, S.Q. Xu \& Strongman, sp. nov. Mycobank MB 513383
Thallus compactus, haptero nodoso amorpho exoriens; trichosporae cylindraceae, $55-90 \times 4.5-5.5 \mu \mathrm{m}$, collo tubulari 5-7.5 $\times 5 \mu \mathrm{m}$ et appendice singulari longa instructae. Zygosporae (Typus II) biconicae, 75-90 × 15$19 \mu \mathrm{m}$, aliquot (plerumque 6) appendices grossas capillaceas ferentes. Ad cuticulam proctodaei larvarum chironomidarum affixus.

Thallus compact, arising from a knobby, amorphous holdfast. Trichospores cylindrical, 55-90 $\times$ 4.5-5.5 $\mu \mathrm{m}$, with a tubular collar 5-7.5 $\times 5 \mu \mathrm{m}$, and a single long, appendage. Zygospores (Type II) biconical, 75-90 × 15-19 $\mu \mathrm{m}$, with multiple (usually six), coarse, hair-like appendages. Attached to hindgut cuticle of chironomid larvae.

Etymology. From the family of the insect host, Chironomidae.

Specimens examined. CHINA. XINJIANG: Urumqi River, Houxia area, $43^{\circ} 13^{\prime} 39.11^{\prime \prime} \mathrm{N} 87^{\circ} 09^{\prime} 10.60^{\prime \prime} \mathrm{E}$ collected 7 Sep 2007. Microscope slide XIN-41 prepared from the hindgut of a chironomid larva (HOLOTYPE SANU). Slide XIN-50 from same host and collection (PARATYPE SANU).

Commentary. Sinotrichium chironomidarum has long cylindrical trichospores, with a collar and a single appendage (FIG. 5) that resemble those of Smittium gigasporus M.C. Williams and Lichtw. (Williams and Lichtwardt 1984). However S. gigasporus typically has a medial swelling while $S$. chironomidarum trichospores are cylindrical and generally longer. In addition $S$. chironomidarum trichospores are similar to the large trichospores in both of the dimorphic species $S$. pseudodimorphum L.G. Valle and Santam. and $S$. heterosporum L.G. Valle and Santam. (Valle and Santamaria 2004) but there is no evidence of dimorphism in S. chironomidarum. The zygospores of S. chironomidarum have multiple appendages (FIGS. 34), while the zygospores of all described Smittium spp. have only one appendage (Misra and Lichtwardt 2000). Trichozygospora chironomidarum has biconical zygospores with multiple appendages similar to $S$. chironomidarum, but the trichospores of $T$. chironomidarum are small and ellipsoidal with many fine appendages (Misra and Lichtwardt 2000).

In this new species asexual and sexual spores were not observed together throughout most of the life cycle. Trichospores are rare or absent when zygospores are produced, but both trichospores and zygospores might be needed for an accurate identification of $S$. chironomidarum and segregation from Smittium spp.

Stachylina tianensis J. Wang, S.Q. Xu \& Strongman, sp. nov. FIGS. 8-11 Mycobank MB 513198

Thallus 130-350 × 10-15 ìm, fundo lobulato bulboso membranam peritrophicam penetranti, 4-25 trichosporas 

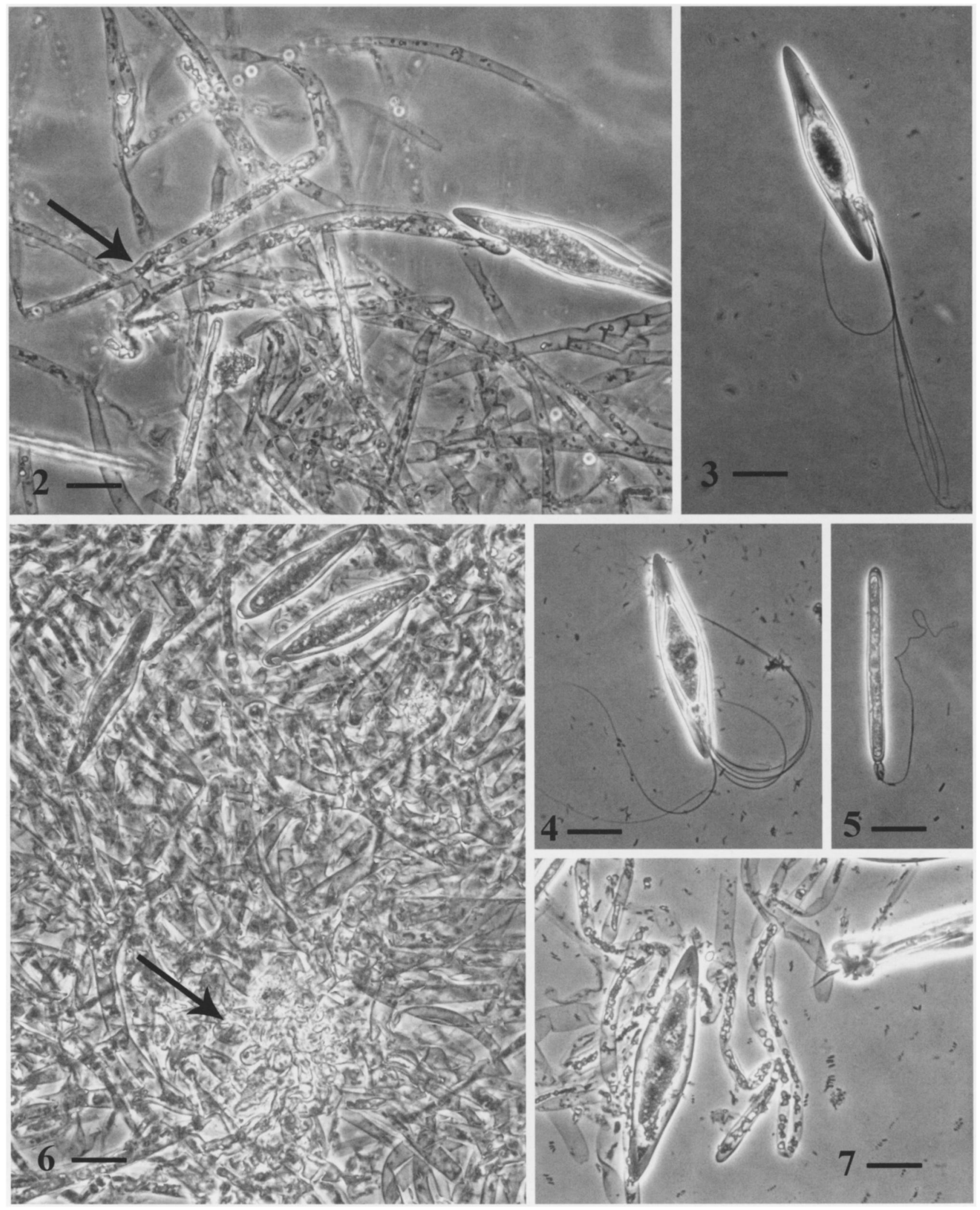

FIGs. 2-7. Sinotrichium chironomidarum. 2. Thalli with conjugating hyphae (arrow), trichospores and a zygospore. 3-4. Released zygospore with multiple appendages. 5. Released trichospore. 6. Compact thallus with a knobby holdfast (arrow). 7. An immature trichospore and a zygospore on the same thallus branch. Bar $=20 \mu \mathrm{m}$. 


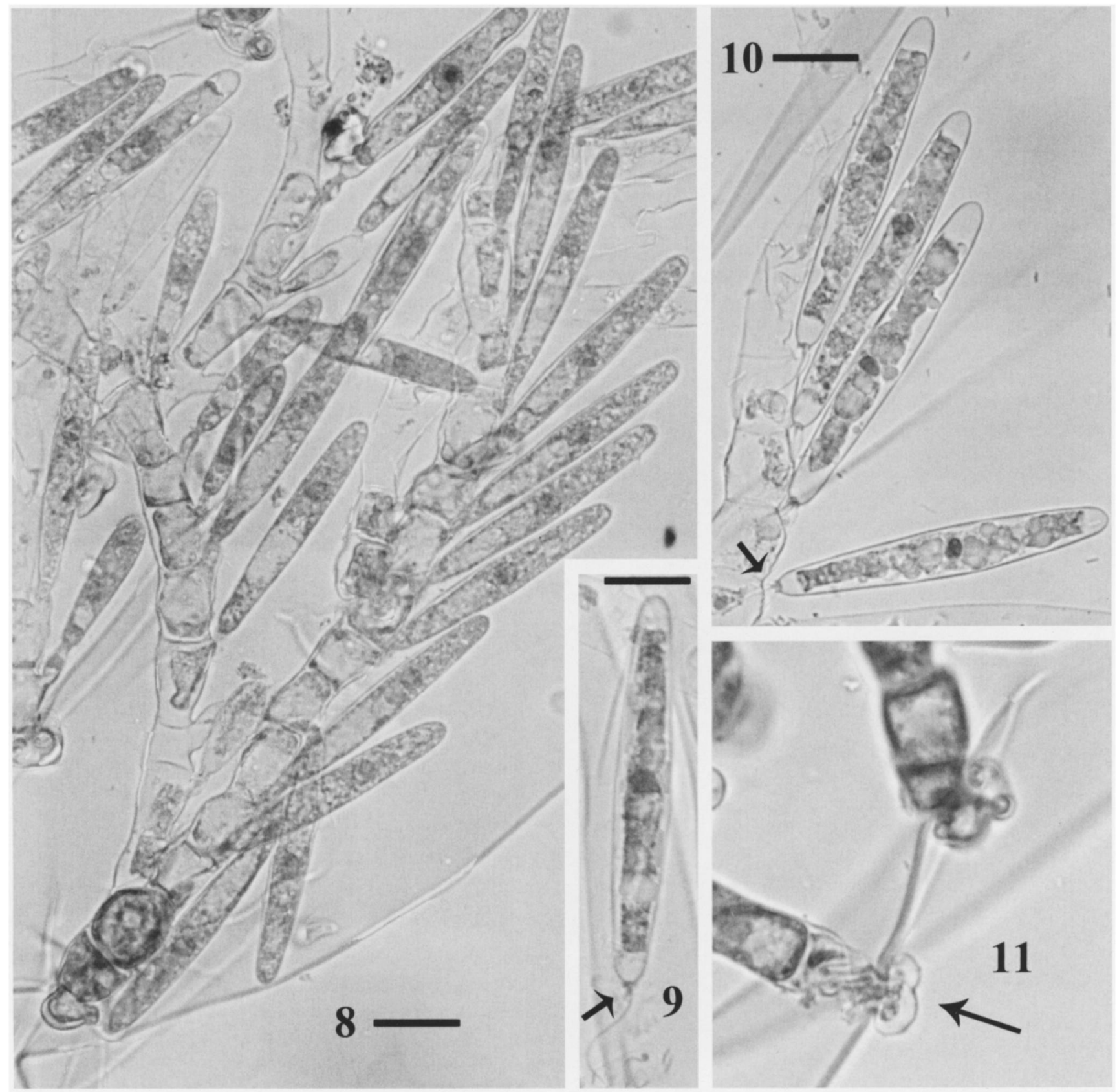

Figs. 8-11. Stachylina tianensis. 8. Thalli with trichospores. 9. A released trichospore with an appendage and a short collar (arrow) 10. Attached trichospores. Note appendage within the generative cell and a short collar (arrow). 11. A lobulate holdfast (arrow) penetrating the peritrophic membrane. Bar $=20 \mu \mathrm{m}$.

procreans. Trichosporae longi-ellipsoideae, 55-90 × 7-10 ìm, appendice singulari et collo brevissimo instructae, in prominentiis-parvis lateralibus a cellula sporogena prodientes, prope septum. Zygoporae non observatae. In membrana peritrophica larvarum chironomidarum.

Thallus 130-350 $\times 10-15 \mu \mathrm{m}$, with a lobulate, bulbous base that penetrates the peritrophic matrix, producing 4-25 trichospores. Trichospores long-ellipsoidal, 55-90 × 7-10 $\mu \mathrm{m}$, with a single appendage and a short collar, produced on small lateral projections from the generative cell, near a septum. Zygospores not seen. On peritrophic matrix of chironomid larvae.

Specimens examined. CHINA. XINJIANG: Urumqi River, Houxia area, $43^{\circ} 13^{\prime} 39.11^{\prime \prime} \mathrm{N} 87^{\circ} 09^{\prime} 10.60^{\prime \prime}$ E collected 21 Aug 2007. Microscope slide XIN-20 prepared from a larva of chironomid (HOLOTYPE SANU).

Etymology. From the Tianshan Mountains of China where the collections were made. 


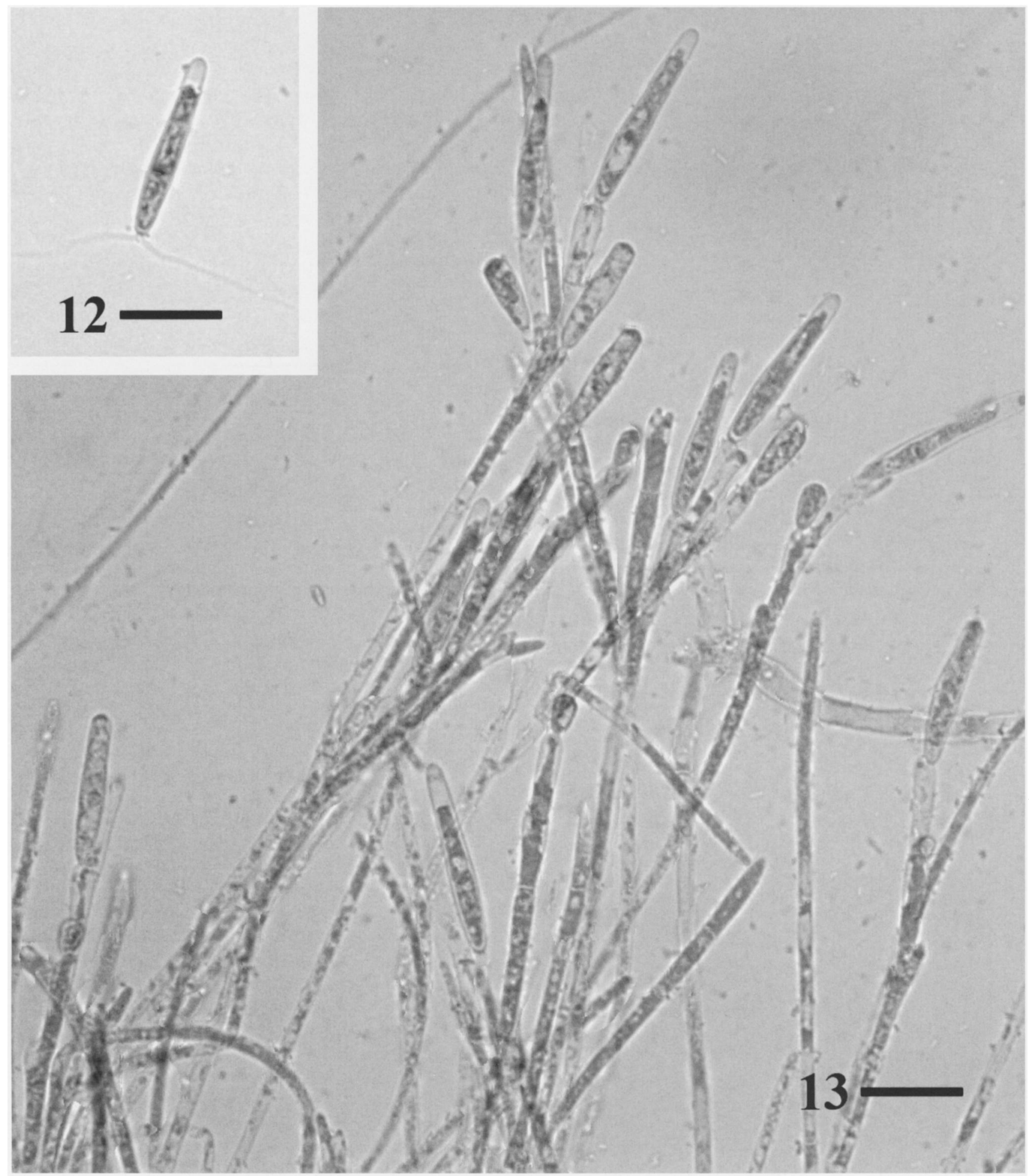

Figs. 12-13. Unknown harpellid fungus, possibly either Lancisporomyces falcatus or Genistelloides communis. Bar $=20 \mu \mathrm{m}$.

Commentary. Including this new species, there are six species of Stachylina with the holdfast penetrating the peritrophic matrix (Lichtwardt et al 2001), but $S$. tianensis differs from the other species in a number of features. All Stachylina spp. with penetrating holdfasts can be separated from $S$. tianensis by trichospore length (Lichtwardt 1973, 1984; Lichtwardt and Williams 1983, 1990). Stachylina stenospora Siri M.M. White and Lichtw. and Stachylina grandispora Lichtw. have trichospores in the same size range but the thalli 
of these fungi do not penetrate the peritrophic membrane as does S. tianensis (Lichtwardt 1972, White et al 2006). The shape of the trichospores and thalli of S. tianensis (Figs. 8-11) are similar to the description for Stachylina magna Indoh, Lichtw. and Kobayasi, but the trichospore size is variable $(30-80 \times$ $6.5-15 \mu \mathrm{m})$, the thalli are larger and the holdfast does not penetrate the peritrophic matrix (Lichtwardt et al 1987), as in S. tianensis.

Other species.-Aside from the new species, the Harpellid Smittium rupestre is recorded from China for the first time. Smittium rupestre was described from Australia (Lichtwardt and Williams 1990), and our collection from Tianshan Mountains in northwestern China fits the description well. We did not find zygospores, but the characteristics of trichospores and thalli match otherwise. This record extends the range of $S$. rupestre to China.

A species of Harpellales collected from stonefly nymphs might be Lancisporomyces falcatus Strongman and M.M. White or Genistelloides communis M.M.White and Lichtw. (Figs. 12-13), but given the overlap in trichospore features in these two species positive identification is difficult without zygospores (Strongman and White 2006, White and Lichtwardt 2004). We also collected protistan trichomycetes, Paramoebidium spp., from the hindgut of Ephemeroptera, Plecoptera nymphs and Diptera larvae. These endosymbionts occur commonly in the hindgut of insects but remain unidentified due to insufficient characters being available.

\section{DISCUSSION}

In this paper we describe a new genus and species, Sinotrichium chironomidarum, and a new species, Stachylina tianensis, from chironomid larvae. Genus Smittium is large and complex, composed of at least 75 species with a great deal of overlap in spore dimensions and other characteristics used to define species. However the medial swelling in most trichospores and the single appendage in both trichospores and zygospores are consistent within the genus (Lichtwardt et al 2001). Sinotrichium, with its long cylindrical trichospores bearing one appendage and the conspicuous zygospores, which have multiple appendages, is sufficiently different to warrant erecting a new genus to accommodate species with this combination of traits. Further study of Smittium spp. might reveal that there are logical divisions within the complex of species that now are assigned to the genus (Lichtwardt et al 2001) and S. chironomidarum would be interesting to include when addressing the taxonomy of this large group.
Genera Austrosmittium and Furculomyces have spore types similar to Sinotrichium, and they are all from Diptera. Genus Austrosmittium has oval trichospores and biconical zygospores with only one appendage (Williams and Lichtwardt 1990), which distinguishes these species from $S$. chironomidarum. Furculomyces has characteristic boomerang-shape zygospores formed from two furculum-like conjugating branches, which is different than all other trichomycete species (Lichtwardt and Williams 1992).

The results of this survey including different habitats along one river suggest that other unexplored areas in China are rich in trichomycetes and there is a need for more collecting to discover and record them.

\section{ACKNOWLEDGMENTS}

We are grateful for the support of the College of Life Science, Shaanxi Normal University (SNNU), and by Biology Department, Saint Mary's University (SMU). This work was part of SNNU-SMU cooperative research. JW thanks her parents for helping with the collections in Xinjiang, and she thanks Ms Lili Zhang, Mr Zhihui Yu, Ms Jianghong Meng, Ms Xiaoning Chen and Ms Jiaxuan Liang for assistance in the field. We also thank Carolyn Bird, Chester Basin, Nova Scotia, for providing the Latin diagnoses and many helpful comments on the manuscript.

\section{LITERATURE CITED}

Adler PH, Wang Z, Beard CE. 1996. First records of natural enemies from Chinese blackflies (Diptera: Simuliidae). Med Ent Zoo 47:291-292.

Chien C-Y, Hsieh Li-H. 2001. Occurrence of Trichomycetes in Taiwan. In: Misra JK, Horn BW, eds. Trichomycetes and other fungal groups. Enfield, New Hampshire: Science Publishers Inc. p 55-72.

Hibbett DS, Binder M, Bischoff JF, Blackwell M, Cannon PF, Eriksson OE, Huhndorf S, James T, Kirk PM, Lücking R, Lumbsch T, Lutzoni F, Matheny PB, McLaughlin DJ, Powell MJ, Redhead S, Schoch CL, Spatafora JW, Stalpers JA, Vilgalys R, Aime MC, Aptroot A, Bauer-R, Begerow D, Benny GL, Castlebury LA, Crous PW, Dai Y-C, Gams W, Geiser DM, Griffith GW, Gueidan C, Hawksworth DL, Hestmark G, Hosaka K, Humber RA, Hyde KD, Ironside JE, Köljalg U, Kurtzman CP, Larsson K-H, Lichtwardt RW, Longcore J, Miadlikowska J, Miller A, Moncalvo J-M, Mozley-Standridge S, Oberwinkler F, Parmasto E, ReebV, Rogers JD, Roux C, Ryvarden L, Sampaio JP, Schüßler A, Sugiyama J, Thorn RG, Tibell L, Untereiner WA, Walker C, Wang Z, Weir A, Weiss M, White MM, Winka K, Yao Y-J, Zhang N. 2007. A higher-level phylogenetic classification of the Fungi. Mycol Res 122:509-547.

Lichtwardt RW. 1972. Undescribed genera and species of Harpellales (Trichomycetes) from the guts of aquatic insects. Mycologia 64:167-197.

1973. The Trichomycetes: What are their relationships? Mycologia 65:1-20. 
1984. Species of Harpellales living within the guts of aquatic Diptera larvae. Mycotaxon 19:529-550.

. 1986. The Trichomycetes: fungal associates of arthropods. New York: Springer-Verlag. 343 p.

-, Cafaro M, White MM. 2001. The Trichomycetes: fungal associates of arthropods. http://www.nhm.ku. edu/ fungi/Monograph/Text/Mono.htm (accessed 1 May 2009).

, Kobayasi Y, Indoh H. 1987. Trichomycetes of Japan. Trans Mycol Soc Japan 28:359-412.

- Williams MC. 1983. Two unusual Trichomycetes in an aquatic midge larva. Mycologia 75:728-734.

-1 . 1990. Trichomycete gut fungi in Australian aquatic larvae. Can J Bot 68:1057-1074.

- - 1992. Furculomyces, a new homothallic genus of Harpellales (Trichomycetes) from Australian midge larvae. Can J Bot 70:1196-1198.

Misra JK, Lichtwardt RW. 2000. Illustrated genera of Trichomycetes, fungal symbionts of insects and other arthropods. Enfield, New Hampshire: Science Publishers Inc. 155 p.
Strongman DB, Xu S. 2006. Trichomycetes from China and the description of three new Smittium species. Mycologia 98:479-487.

, White MM. 2006. New species of Lancisporomyces, Orphella, and Paramoebidium, endosymbionts of stonefly nymphs from stream in Nova Scotia, Canada. Can J Bot 84:1478-1495.

Valle LG, Santamaria S. 2004. The genus Smittium (Trichomycetes, Harpellales) in the Iberian Peninsula. Mycologia 96:682-701.

White MM, Lichtwardt RW. 2004. Fungal symbionts (Harpellales) in Norwegian aquatic insect larvae. Mycologia 96:891-910.

— Siri A, Lichtwardt RW. 2006. Trichomycete insect symbionts in Great Smoky Mountains National Park and vicinity. Mycologia 98:333-352.

Williams MC, Lichtwardt RW. 1984. Two Stachylina and two Smittium species (Trichomycetes) from Montana. Mycologia 76:204-210.

— -1990 . Trichomycete gut fungi in New Zealand aquatic insect larvae. Can J Bot 68:1045-1056. 